\title{
Law Enforcement and Judicial Co-operation in Criminal Matters
}

\author{
GEMMA DAVIES
}

\subsection{Introduction}

The existence of the Common Travel Area (CTA), and its porous nature, has long required significant co-operation between police authorities in the UK and Ireland. Such co-operation predated membership of the EU. For example, the Intergovernmental Agreement on Co-operation in Criminal Justice, the Joint Cross-Border Policing Strategy and the Joint Agency Task Force all serve to enhance and develop effective cooperation between An Garda Síochána (AGS) and the Police Service of Northern Ireland (PSNI), particularly when dealing with organized and cross-jurisdictional crime.

Despite the strength of the working relationship, Brexit presented challenges for co-operation between the UK and Ireland. EU mechanisms had come to replace or complement bilateral co-operation incrementally over twenty years and facilitated or underpinned much of the co-operation enabling a quicker, more efficient and more dynamic response to crime and criminality. If the UK had left the EU without any agreement in place, this would have resulted in the UK losing participation rights in any of the measures adopted under Title $\mathrm{V}$ of the Treaty on the Functioning of the European Union (TFEU). This would have included the loss of a fast-track system of extradition under the European arrest warrant (EAW); quick and efficient exchange of criminal records; access to passenger name records and to rapid DNA and fingerprint matches; exchange of real-time operational information through the Second-Generation Information System (SIS II); and participation in Europol and Eurojust. Continued criminal justice co-operation was recognized as a 'critical justice priority for Brexit negotiations'.

${ }^{1}$ House of Commons Justice Committee, Implications of Brexit for the justice system, 9th report of 2016-17. 
The risks for Northern Ireland were unique. In addition to the loss of cooperation mechanisms, the process of Brexit itself could present increased crime risks depending on how the border between the UK and Ireland was managed. Increases to immigration crime, the smuggling of commodities and a potential resurgence of nationalist or unionist violence in the wake of any intensification of inter-communal tensions heightened the consequences of a 'no deal' scenario. ${ }^{2}$ Although the consequences for Northern Ireland were particularly momentous, local representatives had relatively little freedom to address the issues. Despite responsibility for policing and criminal justice being devolved to the Northern Ireland Executive since 2010, the negotiation of police and judicial co-operation mechanisms with the EU was reserved to the UK government. ${ }^{3}$

Concluding the Trade and Cooperation Agreement (TCA) prevented the cliff-edge consequences that law enforcement and prosecution authorities had been preparing for since 2016. The TCA sets out comprehensive provision in Part 3 for 'Law Enforcement and Judicial Cooperation in Criminal Matters'. With such a short period until the agreement was subsequently ratified and in force, there was little time for parliamentary scrutiny. This chapter seeks to examine the detailed arrangements which will form the basis of co-operation between the UK and the EU for the foreseeable future and asks how well the provisions work for Northern Ireland and the CTA.

\subsection{Extradition between the UK and Ireland}

At the time of the UK's exit from the EU, the extradition relationship between the UK and Ireland was governed by the Framework Decision on the European arrest warrant (EAW). ${ }^{4}$ The EAW provided significant benefits for all participating countries, but these were heightened in the context of the political history of extradition between Ireland and the UK. Extradition between Ireland and Northern Ireland ceased entirely between 1928 and 1965 and was revived only subsequent to both states signing the European Convention on Extradition 1957. ${ }^{5}$ Through the

2 Gemma Davies, 'Facilitating Cross-Border Criminal Justice Cooperation between the UK and Ireland after Brexit: "Keeping the Lights On" to Ensure the Safety of the Common Travel Area' (2020) 852 Journal of Criminal Law 77.

3 Devolution in Northern Ireland, 1998-2020, Briefing Paper CBP9439, February 2020.

${ }^{4}$ Council Framework Decision of 13 June 2002 on the European arrest warrant and the surrender procedures between Member States 2002/584/JHA.

5 European Convention on Extradition, Paris, 13.XII.1957. 
height of the Troubles in Northern Ireland, the extradition of politically motivated offenders from Ireland to the UK was 'by far the most politically contentious issue to have troubled the relationship between these two countries over the last twenty years or so' ${ }^{6}$

The EAW enabled a fast-tracked system of surrender which was made by judicial authorities based on mutual recognition. Member states could not refuse to surrender their own nationals, had limited grounds for refusal, no double criminality requirement and no political offence exception. The EAW was an important tool for the UK and Ireland with the UK being Ireland's biggest 'trading partner'. From September 2018 to August 2019, the PSNI issued thirty-eight EAWs, twenty-six of which related to Ireland and twelve to other EU states. ${ }^{7}$ Conversely, the PSNI received five requests from Ireland during that period, out of a total of forty-four EAWs. ${ }^{8}$ Arnell and Davies demonstrated that there was 'clear evidence that over the last 17 years the EAW has smoothed the extradition waters between Ireland and the UK as both re-embraced the principle of mutual trust and recognition'. ${ }^{\text {? }}$

The UK's departure from the EU inevitably changed this. The need to maintain a functioning system of extradition was identified as a key priority at an early stage of the Brexit process. ${ }^{10}$ Part 3 , Title VII provides for a fast-track system of extradition between the UK and EU member states, still to be known as 'surrender', which replaces the EAW and mirrors the arrangement between the EU and Iceland/Norway, as requested by the UK. Norway and Iceland are full members of Schengen, so this is an unprecedented agreement for a non-EU, nonSchengen country and demonstrates the EU's commitment to finding a way to replicate the EAW provisions as closely as possible.

The new arrangements retain many features of the EAW including the time limits and the limited grounds for mandatory refusal. An annexed

${ }^{6}$ Gerard Hogan and Hilary Delany, 'Anglo-Irish Extradition Viewed from an Irish Perspective' (1993) Public Law 93.

7 Jayne McCormack, 'Brexit: Governments Agree to Replace European Arrest Warrant' (BBC News, 4 September 2019), www.bbc.co.uk/news/uk-northern-ireland-49576159.

${ }^{8}$ Ibid.

9 Gemma Davies and Paul Arnell, 'Extradition between the UK and Ireland after Brexit Understanding the Past and Present to Prepare for the Future' (2020) 85(2) Journal of Criminal Law 98.

10 Department of Justice and Equality, 'Report on the Operation of the European Arrest Warrant Act 2003 (as Amended) for the Year 2017', p 4, www.justice.ie/en/JELR/ European_Arrest_Warrant_Annual_Report_for_2017.pdf/Files/European_Arrest_Warrant_ Annual_Report_for_2017.pdf. 
pro forma substantially replicates the pro forma used for EAW requests, ensuring familiarity for practitioners. Most importantly for the UK and Ireland, the system remains a judicial one and not political. There are, however, several key differences from the EAW. Article 597 provides that co-operation should be 'necessary and proportionate, taking into account the rights of the requested person and the interests of victims, having regard to the seriousness of the act, the likely penalty that would be imposed and the possibility of ... less coercive measures'. This is similar to the proportionality bar prescribed in section 21A Extradition Act 2003 (EA 2003) which was an invention of UK extradition law not deriving from the EAW. However, proportionality in Title VII is broader than the bar in the EA 2003 since it applies to both accusation and conviction arrest warrants.

Proportionality is now an overarching principle relevant to the whole of the surrender proceedings. Section 21A of the EA 2003 is unamended and it will be for the courts to consider whether the approach to proportionality will change. There is no 'trial readiness' bar mirroring section 12A EA 2003, only oblique reference in TCA Article 597 to 'avoiding unnecessarily long periods of pre-trial detention' as a material consideration of proportionality. The English High Court has clarified that the starting point for any analysis of the provisions was the relevant domestic legislation - the EA 2003 - and not any unincorporated international agreement which was not part of UK domestic law. ${ }^{11}$

There are three new grounds for refusal. First, Article 602 introduces a political offence exception. Parties may notify the Specialised Committee on Law Enforcement and Judicial Cooperation (SCLE\&JC) that the general exception against refusal on the grounds that the offence may be regarded as a political offence will apply only to certain offences. ${ }^{12}$ Neither Ireland nor the UK has, however, made such a declaration. In any event, section 13 EA 2003 already bars, as an extraneous consideration, extradition that appears to be issued for the purpose of prosecuting or punishing on account of 'political opinions'. The political offence exception is not identical to section 13 EA 2003; it relates only to offences that are clearly political in character. It is likely that the exception will cover very few cases and will not affect extradition requests to the UK from Ireland or vice versa.

${ }^{11}$ Polakowski \& others $v$ Westminster Magistrates' Court [2021] EWHC 53.

12 As specified in TCA Art 602(2) which includes the offences referred to in Arts 1 and 2 of the European Convention on the Suppression of Terrorism 1977 and falling within the definition of terrorism under Annex 45 of the TCA. 
Second, states may now refuse to surrender their own nationals, or agree to surrender them but only under certain conditions. Ten countries have issued such a derogation, but Ireland has not. ${ }^{13}$ However, there is a requirement that where a party refuses to surrender its own nationals, it must consider whether they can be prosecuted for an offence of commensurate seriousness under domestic law.

Third, dual criminality - where an offence must exist in both jurisdictions - is now required for extradition, except in defined circumstances, although this may be waived. The UK has chosen to require dual criminality in all cases at present, although Ireland has waived the requirement. ${ }^{14}$ It is open to the UK to notify the SCLE\&JC that it will apply the 'list-system' of offences which do not require dual criminality in the future. The UK and Ireland - both common law countries - have greater alignment in relation to criminal offences than the UK has with civil law countries. ${ }^{15}$ The TCA also specifies certain rights for the accused, including the right to an interpreter and a lawyer in both the requesting and the executing state, in accordance with domestic law. There is no specific right to legal aid, as initially requested by the EU.

Surrender under Title VII is no longer underpinned by mutual recognition and trust and is instead premised on the principle of proportionality and judicial dialogue between requesting and issuing states. In an Irish High Court case, the applicant argued that, by reason of the manner in which he had conducted his defence, he was at risk of being subjected to violent assault from organized criminals in detention in the UK. ${ }^{16}$ Counsel on behalf of the respondent submitted that, as the UK had withdrawn from the EU, the principle of mutual trust and confidence between EU member states no longer applied to the UK. The UK might also in the future withdraw from the Council of Europe and also change its domestic law so as to deprive persons surrendered of the rights currently enjoyed under the European Convention on Human Rights (ECHR). The Irish Court robustly dismissed the respondent's objections

${ }^{13}$ Croatia, Finland, France, Germany, Greece, Latvia, Poland, Slovakia, Slovenia and Sweden have notified their intention to exercise an absolute bar on extradition of own nationals. Further, Austria and the Czech Republic will only extradite their own nationals to the UK with their consent. See Home Office letter to the House of Lords EU Security and Justice Sub Committee, 5 March 2021, https://committees.parliament.uk/writtenevi dence/23544/pdf/.

14 Ibid.

${ }^{15}$ Liz Heffernan, 'Irish Criminal Trials and European Legal Culture: A Backdrop to Brexit' (2020) 85(2) Journal of Criminal Law 144.

${ }_{16}$ Minister for Justice and Equality v Delano Demetrius Brissett [2021] IEHC 95. 
and ordered his surrender to the UK, but the case demonstrates the potential for increased challenge to surrender. How the courts will approach surrender cases outside of mutual trust and recognition has yet to be seen.

TCA Articles 607 and 608 establish various methods of transmitting an arrest warrant, the preferred method being secure transfer between judicial authorities. This works well if the location of the suspect is known. If the location of the suspect is unknown then, in the absence of UK access to SIS II, TCA Article 608(2) gives power to Interpol to facilitate transmission. However, the issuing judicial authority 'may transmit the arrest warrant by any secure means capable of producing written records'. Ireland has only very recently linked to SIS II and so historically EAWs were always bilaterally shared. The TCA provisions allow this to continue. The UK has lost access to SIS II which allows for real-time sharing of data relating to wanted or missing persons or objects. This database was consulted almost 600 million times by UK police forces in 2019 and the impact on the PSNI will have to be monitored. AGS became fully operational with SIS II in March 2021, but SIS II rules state that 'data processed in SIS and the related supplementary information exchanged pursuant to this Regulation shall not be transferred or made available to third countries or to international organisations. ${ }^{17}$ Co-operation on operational information will be much more efficient if there is a colocated joint operational centre between AGS and PSNI modelled on the highly functional Nordic police co-operation. ${ }^{18}$

Legal proceedings relating to the operation of extradition between Ireland and the UK post-Brexit are still ongoing at the time of writing and could yet derail extradition. ${ }^{19}$ Ireland is subject to Protocol No 21, annexed to the TFEU which provides for the reservation of sovereignty by Ireland in respect of the Area for Security, Freedom and Justice (ASFJ). The validity of the legal basis for extradition between Ireland and the UK rests on the question (which has been referred by the Irish Supreme Court to the Court of Justice of the European Union (CJEU)) of whether the Withdrawal Agreement and/or the TCA bind Ireland insofar as those agreements relate to matters within the ASFJ. If the CJEU were to agree with the Appellant's arguments, 'it would have the effect of

17 Regulation (EU) 2018/1862, Art 65.

18 Davies (n 2).

19 Hasnain Saqlain $v$ The Governor of Cloverhill Prison \& Salman Shahzad $v$ The Governor of Mountjoy Prison [2021] IESC 45 (unapproved judgment of Mr Justice Clarke, Chief Justice, delivered 20 July 2021) (Irish Supreme Court). 
significantly watering down any protocols negotiated in respect of the ASFJ and could, indeed, have implications for any areas of competence where a Member State ... had negotiated a retention of sovereignty by means of a protocol'. ${ }^{20}$

\subsection{Exchange of Information between the UK and Ireland}

The TCA provides for timely exchanges of passenger name records for air travel in TCA Title III and the transfer of DNA data, fingerprint information and vehicle registration data in TCA Title II. In relation to Title II, there are provisions for an 'evaluation visit and pilot run' which may result in a commencement delay to these provisions after a nine-month initial grace period. ${ }^{21}$ Overall, the provisions for the exchange of data are very similar to those operating before Brexit. The UK had wanted to exchange passenger records for rail and sea travel as well, but this has not been included in the TCA. This is an area where bilateral exchange between the UK and Ireland could enhance the safety of the CTA.

Under TCA Title IX, states have a continued obligation to inform each other of criminal convictions handed down within their territory. This importantly ensures that at least one state has a complete record of all convictions no matter where they are handed down in the EU. While the UK is no longer part of the European Criminal Records Information System (ECRIS), the new provisions correspond closely with it. Exchange still happens based on a request, but the provisions do not cover exchange of information on convictions of third-country nationals, an aspect of ECRIS that the EU is seeking to expand. The time limits are not as short as with ECRIS, communication of convictions handed down in a state to the states of the convicted persons' nationality is done once a month rather than 'as soon as possible', and requests must be replied to within twenty, instead of ten, days. ${ }^{22}$ Although the UK technically loses access to ECRIS, EU states will continue to use it in their co-operation with the UK. The UK, however, 'shall be responsible for the development and operation of its own interconnection software'. ${ }^{23}$ The UK is now using the UK's Criminal Record Information System (UKCRIS) to connect with member states' exchange software. The disruption to criminal record exchange between the UK and the EU should be minimal and,

20 Ibid [8.2].

21 TCA Art 540.

22 TCA Art 649.

23 TCA Annex 44, Art 3(3). 
although the maximum time limits have increased, the UK and Ireland can aim for quicker exchange.

Previously, the UK could send a European investigation order (EIO) to countries within the $\mathrm{EU}$ - a legally binding request to gather evidence by a specific deadline - but this is now lost. TCA Title VIII sets out a replacement which sees the UK fall back on the Mutual Legal Assistance Convention 1959 with some supplementation. ${ }^{24} \mathrm{~A}$ form for a request for mutual assistance is envisaged, but has not been agreed. This has been tasked to the SCLE\&JC. In the interim, states must make requests through letters rogatory. Availability of evidence to the UK as a third party will depend on the legal situation in each member state. As Ireland has not yet joined the EIO, there is no loss of co-operation in this area. There is no mechanism in TCA Part 3 to replace the suite of Framework Decisions which facilitate transfer of custodial sentence, pre-trial bail or probation supervision between member states. ${ }^{25}$ Bilateral co-operation could be explored between the UK and Ireland in this area to further facilitate free movement across the CTA. ${ }^{26}$ Prisoner transfer between the UK and Ireland has been beset by legal challenge and delay in recent years and bilateral agreements could enhance the rehabilitation of offenders. ${ }^{27}$

The TCA provides a framework for co-operation with Europol and Eurojust in Titles V and VI, respectively, which guarantee certain operational capability and data sharing but also reflect the fact that the UK is a third country. The extent of the relationship is not yet fleshed out and TCA Article 577 states that working arrangements complementing or implementing this Title may be made. Importantly, the UK will be able to

${ }^{24}$ European Convention on Mutual Assistance in Criminal Matters [1959] COETS 3, Strasbourg 20.IV.1959.

${ }^{25}$ Framework Decision 2008/909/JHA of 27 November 2008 on the application of the principle of mutual recognition to judgments in criminal matters imposing custodial sentences or measures involving deprivation of liberty for the purpose of their enforcement in the European Union; Council Framework Decision 2009/829/JHA of 23 October 2009 on the application, between Member States of the European Union, of the principle of mutual recognition to decisions on supervision measures as an alternative to provisional detention; Council Framework Decision 2008/947/JHA of 27 November 2008 on the application of the principle of mutual recognition to judgments and probation decisions with a view to the supervision of probation measures and alternative sanctions.

26 Tim Wilson, 'Prisoner Transfer within the Irish-UK Common Travel Area (CTA) after Brexit: Human Rights between Politics and Penal Reform' 85(2) Journal of Criminal Law 121.

27 Report of the Minister for Justice and Equality Charles Flanagan to the Houses of the Oireachtas on the operation of the Transfer of Sentenced Persons Acts 1995 and 1997 for the period 1 January 2018-31 January 2018. 
assign one or more liaison officers to Europol, one liaison prosecutor with up to five assistants to Eurojust (and vice versa). These officers will be able to attend operational meetings on invitation. The UK will also be able to take part in operational analysis projects as well as attend the Europol Heads of Unit meeting as an observer and participate in Joint Investigation Teams.

\subsection{Oversight and Ancillary Concerns}

TCA Part 3 has its own rules on dispute settlement and introduces the SCLE\&JC, one of the bodies established under the umbrella of the Partnership Council. It has a role in governance of the agreement as well as in dispute resolution, and it will be central to the stability of TCA Part 3 and, one hopes, to its expansion in future years. If a mutually agreed solution to a dispute is not reached, this could lead to suspension of TCA Part 3 or some of its Titles. It will be important that Northern Ireland and the other devolved nations are represented on the Committee.

There are certain aspects of the Northern Ireland Protocol which may come into play in relation to Part 3. Protocol Article 2 ensures 'no diminution of rights, safeguards or equality of opportunity' as protected in the 1998 Agreement. ${ }^{28}$ Protocol Article 11 states that the Protocol shall be implemented and applied 'so as to maintain the necessary conditions for continued North-South cooperation, including in the area of ... justice and security'. The close level of co-operation set out in TCA Part 3, the detailed data protection provisions and the similarity to preexisting provisions ensure that there is no immediate discernible loss of rights for either UK citizens or Irish citizens. However, in the future there are certain areas which are vulnerable to such developments. Law enforcement access to personal data is an area that could see a divergence in rights protection and has already been raised as a concern in relation to the UK obtaining a data adequacy decision.

Although the European Commission adopted data adequacy decisions based on the General Data Protection Regulation (GDPR) and the Law Enforcement Directive for the UK in late June 2021, for the first time a sunset clause has been included. The decision to limit the duration of adequacy to four years reflects the European Data Protection Board's concerns about the UK's surveillance regime and the challenges of

28 See further Chapter 12. 
redress in the areas of national security. ${ }^{29}$ This particularly related to bulk interceptions, the use of automated processing tools, and safeguards in relation to overseas disclosure. The Civil Liberties, Justice and Home Affairs (LIBE) Committee of the European Parliament also subsequently passed a resolution urging the European Commission to address these concerns in its proposed adequacy decision. It is clear that the EU will continue to monitor the UK's data protection regime and is able to intervene at any point if it believes that the UK does not ensure an adequate level of protection. Law enforcement and security services' access to bulk personal data and its processing and retention are clearly areas of contention and possible future divergence.

Such divergences could not only threaten the continuance of the data adequacy decisions but also engage the Northern Ireland Protocol if Irish citizens were afforded greater protection of rights than British citizens. The Northern Ireland Human Rights Commission, and the Joint Committee of representatives of the Human Rights Commissions of Northern Ireland and Ireland are well placed to consider the implications of the Northern Ireland Protocol for the operation of TCA Part 3. Although the courts in Northern Ireland will undoubtedly also have these aspects of the Protocol in mind, representation from Northern Ireland on the SCLE\&JC and bringing criminal justice co-operation under the remit of the British-Irish Council should ensure that these important aspects of the operation of TCA Part 3 are not overlooked. It will be essential to the stability of Part 3 that the UK ensures continued alignment of data protection rules.

Part 3 is also based on respect for the protection of fundamental rights and freedoms of individuals, including participation in the ECHR, as well as the importance of giving effect to it domestically'. ${ }^{30}$ There is a form of fast-track termination in the event of denunciation of the ECHR or one of three protocols which becomes effective on the date of denunciation. ${ }^{31}$ There are also clauses on suspension as distinct from termination in the case of 'serious and systemic deficiencies within one Party as regards the protection of fundamental rights or the principle of the rule of law, ${ }^{32}$ There is no explicit reference to amending or scrapping domestic law giving effect to the ECHR as triggering termination, but these provisions

29 European Data Protection Board Opinion 14/2021 and 15/2021 on the European Commission draft Implementing Decisions on the adequate protection of personal data in the United Kingdom.

30 TCA Art 524.

31 TCA Art 692.

32 TCA Art 693. 
will need to be considered carefully by the UK government during the independent review of the Human Rights Act 1998 (HRA 1998) which has not yet reported at the time of writing. The HRA 1998 is intrinsically linked to the UK's adherence to the ECHR and 'the Government's ongoing application of the ECHR is important in facilitating continued data sharing and effective extradition arrangements between the UK and Ireland'. ${ }^{33}$

\subsection{Conclusion}

The TCA could never replicate the level of law enforcement and judicial cooperation the UK enjoyed as an EU member state. However, without an agreement, co-operation between the UK and the EU would have relied on outdated international instruments which would have been significantly slower and less effective. The UK and the EU have secured co-operation that is as close as conceivable in many areas, particularly in light of the UK's insistence that the CJEU play no role in overseeing any aspect of the TCA. In many respects, therefore, it represents a good working compromise. However, the loss of real-time data and the reduction of UK influence in Europol and Eurojust will have an operational impact for UK police. There are also areas where co-operation between the UK and Ireland, and in particular the PSNI and the AGS, could be enhanced through bilateral agreement. Co-operation on operational information will best be facilitated through a co-located joint operational centre for the PSNI and the AGS.

The arrangements in TCA Part 3 are complex to put into place and will require a long period of readjustment. Legal challenges have already been made to important aspects of the operation of Part 3. It will therefore be some time before the full consequences and operational reality of the TCA will be felt. A continued high level of cross-border operational cooperation is therefore more important than ever. The implementation of the Northern Ireland Protocol holds opportunities for smugglers and organized gangs on the island of Ireland. Moving criminal justice cooperation within the remit of the British-Irish Council and ensuring formal input of devolved representatives on the SCLE\&JC could ensure that police and judicial co-operation on the island of Ireland has the prominence that it deserves.

${ }^{33}$ House of Commons, Northern Ireland Affairs Committee, 'Cross-Border Co-operation on Policing, Security and Criminal Justice after Brexit', 4th report of 2019-21 at para 115. 